\title{
URBAN LAND USE PLANNING
}

URBAN LAND USE PLANNING, by F. Stwart CHAPIN, Jr. Harper and Brothers New York: 1957. pp: $X V+388$

Șehir ve bölge plânlamasında sosyal ve ekonomik faktörlerin hesaba katılması gereğinin gittikçe daha geniş bir şekilde kabul ve tatbik edilmekte olduğu görülmektedir. Bu alanda yapılan son yayınlar bu gözlemi destekler mahiyettedir. Isste, Stuart Chapin'in "Urban Land Use Planning" başlığını taşıyan eseri bu bakımdan önem ve değer taşımaktadır. Gerçekten, yazar mekân plânlamasinın dayandığı sosyal ve ekonomik faktörleri belirtmek, gerekli araștırma ve tahlilleri göstermek, bu konudaki belli başh görüşleri gözden geçirmek yönünden șehir ve bölge plânlaması disiplinine büyük bir katkıda bulunmuş olmaktadır.

Eserini üç ana bölümde toplayan yazar, ilk bölümde topraktan faydalanmayı tayin eden faktörleri incelemektedir. Birinci bölïmün ilk kesiminde yazar, münferit bir arsa parçasının kullanılmasına etkide bulunan ekonomik faktörleri kısaca belirttikten sonra, bütün bir şehir arazisinin kullanılma șeklini ele alarak ekoloji konusundaki ana görüşleri tahlilî bir açıdan gözden geçirmektedir. Kasımın sonunda, şehir topraklarının kullanılması hakkındaki ekonomik nazariyelerin șehir ve bölge plânlaması ameliyesile: münasebeti üzerinde durulmaktadır.

Birinci bölümün ikinci kesimi topraktan faydalanmaya etkide bulunan sosyal faktörlere ayrılmıştır. Bu kesimde çeşitli sosyal durum, davranıș ve değerlerin topraktan faydalanmağa ne gibi etkilerde bulunduğuna dair açıklamalarda bulunduktan sonra yazar, bunların mekân plânlamasıyla ilgisini kurmağa çalıșmaktadir.

Aynı bölümün üçüncü kesiminde topraktan faydalanma faktörï olarak «kamu yararı» kavramı ele alınmakta, kamu sağlığı ve güvenliği, kamu hizmetleri, fizikî karakteristikler, malî imkânlar, hukukî mülâhazalar, siyasal iklim gibi çeșitli etkenler üzerinde durulmaktadir.

Dördüncü kesimde ise, üç kesimde ayrı ayrı incelenen bu faktörlerin karşılıklı münasebetleri açıklandıktan sonra mekân plânlamasına uygulanması esaslari belirtilmektedir.

Eserin ikinci ana bölümü topraktan faydalanmanın plânlan- 
ması için gerekli araştırma ve tahlillere ayrılmıștır. Bu bölümün ilk kesimini teșkil eden beşinci kesim șehir ekonomisi konusuna ayrılmış bulunuyor. Yazar, bu konudaki tutuş tarzlarını biri bölgesel esaslara, diğeri de șehir merkezinin ekonomik tabanına istinat ettiren tutuş tarzları olarak başlıca iki ana gurupta incelemekte, bunlar hakkında açılayıcı bilgiler verdikten sonra, yapılan tenkidlere de temas etmekte, șehrin ekonomik varlığıın topraktan faydalanma bakımından önemini belirtmektedir.

Altıncı kesim, çalıșma ve işgücü araștırmalarımı konu edinmiștir. Çalıșma ve işgüicü araștırmalarının mekân plânlaması bakımından önemi açıklandıktan sonra, gelecekteki çalıșma temayüllerinin önceden tahmin edilebilmesi için kullanılan analiz metodları açıklanmakta, yapılmış tahmin ve tahlillerden örnekler verilmektedir.

Yedinci kesimin konusu nüfus araștırmalarıdır. N/̈̈fus temayüllerinin belirtilmesinde, gelecekteki nüfusun tahmininde kullanılan usulleri açıklıyan yazar, kesimin sonunda nüfus ile arazi arasındaki münasebeti plânlama açısından tetkik etmektedir.

Sekizinci kesim șehir arazisinin tetkikine ayrılmıș bulunuyor. Şehir arazisinin çeşitli amaçlar için kullanılma çeşitlerini, faydalanma şekillerini tespit için girișilecek araştırmalarda tutulacak yollar șehir kurulușunun haritaya işlenmesi, referans ve taban haritalarının çeșitleri ve hazırlanması, kullanılış ve faydalanma tarzlarının simiflandırilması, survey'in yapılması, elde edilen bilgilerin haritaya geçirilmesi, kullanılmayan arsaların tetkiki, binaların halihazır durumlarının tespiti ve sinflandırılması, survey tekniği, analiz metodları, gibi konular bu kesimde ele alınmaktadır. Keza, arsa değerleri, binaların estetik karakterleri hakkındaki arașturmalar da bu kesimde incelenmektedir.

Dokuzuncu kesim, ulaștırma ile araziden faydalanma arasındaki bağıntıya ayrılmıştır. Bu kesimde ulaştırma, daha doğrusu yol şebekesi yapılırken incelenecek konular ve uygulanacak esaslar gözden geçirilmèktedir.

Kitabın son ana bölümü plânlama ameliyesini konu edinmektedir. Bu bölümüin ilk kesimi olan Onuncu Kesimde, topraktam faydalanma plânlarının unsurları, hazırlaama tekniği ve çizimi hakkında bilgiler yer almaktadır. 
Onbirinci Kesimde, çeşitli amaçlar için arazi ayrulırken, kuruluş yeri bakımından uyulacak genel prensipler ve uygulanacak ölçüler açıklanmaktadır. Belli amaçlar için ayrılması gereken arsa yüzeyleri konusu ise ayrı bir başlık altında on ikinci kesimde ele alınmıştır.

Kitabın son kesimi, "araziden faydalanma plânı» hakkındadır. Bu kesimde bu plânın çizimi, takdimi, malî yönü, araziden faydalanma için yapılan plânlamanın vatandaş ve kamu makamları tarafından nasıl anlaşıldığı, bu anlayışlarda ne gibi değișiklikler gerektiği konuları yer almaktadır.

Kısaca belirtmek gerekirse, S. CHAPIN'in bu kitabı araziden faydalanmayı gösteren fizikî plânlamada başarı için gerekli sosyal ve ekonomik esasları sistematik bir şekilde incelemesi, bu konudaki görüş̧leri ve bunlara karșı ileri sürülen tenkidleri plâncının önüne derli toplu șekilde sermesi sebebiyle șehir ve bölge plânlamasının fizikî veçhesiyle meşgul olanlar kadar onun sosyal ve ekonomik yönleriyle ilgilenenler için de ilgi çekici ve faydalı bir eser intibain burakmaktadır. 